\title{
Effect of Adhatoda vasica (Acanthaceae) on Antioxidant and Immunological Profile in Sheep
}

Shiny Joy ${ }^{1}$, P. Eswara Prasad ${ }^{1}$, K. Padmaja ${ }^{1}$, K. Adilaxamamma², V. Chengalva Rayulu ${ }^{3}$, G. Gangaraju ${ }^{4}$

10.18805/IJAR.B-4755

\section{ABSTRACT}

Background: A study was conducted to evaluate the antioxidant and immunological profile of methanolic extract of Adhatoda vasica leaves (AVE) in naturally infected sheep with gastrointestinal nematodes and compared with commonly used anthelmintic albendazole in sheep.

Methods: Fifty four sheep found positive for gastrointestinal nematodes were divided into 3 equal groups, GI (infected-untreated: control), GII (infected- AVE treated) and GIII (infected- albendazole treated). Blood samples were drawn on $5^{\text {th }}$ and $14^{\text {th }}$ day after treatment for analysis of oxidative stress markers such as TBARS, TAC, SOD and catalase and immunological parameters such as total immunoglobulin, IgG and IL-10.

Result: Helminthiasis in sheep cause a considerable oxidative stress. The anthelmintic activity of Adhatoda vasica surpassed the conventional synthetic drug albendazole in sheep in terms of oxidative and immunological changes in blood.

Key words: Adhatoda, Catalase, Helminthiasis, IL-10, Immunoglobulin, SOD, TAC, TBARS.

\section{INTRODUCTION}

Gastrointestinal (GI) parasitic infections cause a significant loss of productivity and reproductivity in terms of reduced milk, meat and wool production, loss of weight, inefficiency of food utilization, reproductive fitness and mortality in severe infections (Charlier et al. 2014). Besides, helminth positive cases show considerable oxidative stress. They further cause the development and progression of several diseases.

Plants have an innate ability to synthesize nonenzymatic antioxidants capable of attenuating ROS-induced oxidative damage. Adhatoda vasica Nees, belonging to the family Acanthaceae, is widely distributed in the tropical and semitropical region of the Indian subcontinent and other Asian countries. Due to rich concentration of quinazoline alkaloids like vasicine (Soni et al. 2008), it has shown anthelmintic activity in their roots and aerial parts (Lateef et al. 2003; Al-Shaibani et al. 2008). The extract of leaves has shown potent antioxidant (Adhikary et al. 2016) and immunostimulatory (Vinothapooshan and Sundar, 2011) effect in laboratory animals.

The present study has attempted to compare the effect of herbal anthelmintic Adhatoda vasica on antioxidant and immunological profile and compared to that of conventional anthelmintic - albendazole in sheep.

\section{MATERIALS AND METHOdS}

The leaves of Adhatoda vasica were procured from the vicinity of College of Veterinary Science and Tirumala hills of Tirupati (Andhra Pradesh). The plant was identified and authenticated by taxonomist from the department of Botany, Sri Venkateswara University, Tirupati. Adhatoda vasica methanolic leaf extract (AVE) was prepared by using cold
${ }^{1}$ Department of Veterinary Biochemistry, College of Veterinary Science, Tirupati-517 502, Andhra Pradesh, India.

2Department of Veterinary Pharmacology and Toxicology, College of Veterinary Science, Tirupati-517 502, Andhra Pradesh, India.

${ }^{3}$ Department of Veterinary Parasitology, College of Veterinary Science, Tirupati-517 502, Andhra Pradesh, India.

${ }^{4}$ Livestock Research Station, Sri Venkateswara Veterinary University, Palamaner-517 408, Andhra Pradesh, India.

Corresponding Author: Shiny Joy, Department of Veterinary Biochemistry, Nagpur Veterinary College, Nagpur-440 006, Maharashtra, India. Email: shiny.joy@gmail.com

How to cite this article: Joy, S., Prasad, P.E., Padmaja, K., Adilaxamamma, K., Rayulu, V.C. and Gangaraju, G. (2022). Effect of Adhatoda vasica (Acanthaceae) on Antioxidant and Immunological Profile in Sheep. Indian Journal of Animal Research. DOI: 10.18805/IJAR.B-4755.

Submitted: 21-08-2021 Accepted: 25-11-2021 Online: 11-01-2022

maceration method. The semi-solid consistency green extract yield obtained was $10.29 \%$ with reference to soaked sample material.

The experiments were conducted in sheep of Nellore Jodipi breed maintained at Livestock Research Station, Palamaner, India. Adult male and female (not pregnant) sheep above 1 year of age weighing $20-30 \mathrm{~kg}$ and not treated with any anthelmintic drug at least 8-12 weeks were selected for the present trial. 54 such sheep were randomly allocated into 3 equal groups containing 18 sheep in each, GI (infected-untreated: control), GII (infected- AVE treated) and GIII (infected- albendazole treated). AVE was administered to Gll animals at the rate of $500 \mathrm{mg} \mathrm{kg}^{-1}$ body weight once in $1 \%$ carboxymethyl cellulose solution by oral drenching. 
Animals of GIII were treated with a single oral dose of albendazole at the rate of $5 \mathrm{mg} \mathrm{kg}^{-1}$ body weight as recommended by the manufacturer company (Virbac Animal Health Pvt. Ltd., India). Animals of GI were kept as positive control group. On the $5^{\text {th }}$ and $14^{\text {th }}$ day, blood samples were collected and analysed for oxidative and immune status.

The whole blood sample collected in EDTA vaccutainers was centrifuged at $3000 \mathrm{rpm}$ for 10 minutes. The plasma was harvested and Thiobarbituric Acid Reactive Substance (TBARS) was estimated by the method of Ohkawa et al. (1979). The erythrocyte sediment was used for the preparation of $25 \% \mathrm{v} / \mathrm{v}$ hemolysate solution with chilled distilled water. The hemolysate was used for the estimation of Total Antioxidant Capacity (TAC) and activities of superoxide dismutase (SOD) and catalase. Since glutathione is the most concentrated intracellular species that plays a crucial role in protection from free radicals, TAC was assayed according to the method of Ciuti and Liguri (2017) and expressed in terms of $\mathrm{mM}$ of reduced glutathione equivalents per gram of haemoglobin. The results were normalized with respect to sample's haemoglobin. SOD activity was measured according to Misra and Fridovich (1972). One unit of SOD activity was defined as the amount of enzyme required to cause $50 \%$ inhibition of adrenaline auto-oxidation and expressed as $\mathrm{U} / \mathrm{g} \mathrm{Hb}$. Catalase activity was measured according to the method of Aebi (1984) and expressed as $\mathrm{U} / \mathrm{g} \mathrm{Hb}$.

Serum samples were used to estimate total immunoglobulins (TIg), IgG and IL-10. Species-specific sheep immunoglobulin $G$ ( $\lg G)$ ELISA kit was purchased from Bioassay Technology Laboratory, China and procedure followed as per manufacturer's instructions. The result of $\lg G$ was expressed in $\mathrm{mg} / \mathrm{mL}$. Species-specific sheep Total Immunoglobulin (Tlg) ELISA kit was purchased from Abbkine Inc, China and procedure was followed as per manufacturer's instructions. Species-specific sheep Interleukin 10 (IL-10) ELISA kit was purchased from Bioassay Technology Laboratory, China and procedure followed as per manufacturer's instructions. The results of $\mathrm{IL}-10$ were expressed in $\mathrm{ng} / \mathrm{L}$.

For statistical analysis of data of oxidative stress, antioxidant status and immune status parameters were analysed in relation to sampling date. The results obtained were tabulated and subjected to analysis through software IBM SPSS Statistics-22, 2013 using the general linear model. Results were expressed as arithmetic mean \pm SE. The differences between means were compared by Duncan's multiple range test. Differences were considered significant at $p \leq 0.05$ level of probability.

\section{RESULTS AND DISCUSSION}

\section{Oxidative status}

The oxidative stress marker and antioxidant status in experimental groups is shown in Table 1.

\section{TBARS}

The TBARS value observed in the group I were significantly higher than groups II and III and were in agreement with Cinar et al. (2018) where increased erythrocyte MDA levels were reported in naturally infected Dicrocoelium dendriticum and hydatid cyst in sheep; Rashid and Irshadullah (2019) in helminth infected goats. The increase in the MDA levels observed with helminth infection in sheep could be attributed to reduced activity of the antioxidant defense system. Attenuation of lipid peroxide generation using AVE observed in group II, is in harmony with findings reported by Adhikary et al. (2016) in collagen-induced arthritis in mice. In the present experiment, value of TBARS recorded in group III was significantly higher than group II on $5^{\text {th }}$ and $14^{\text {th }}$ day. Also, the TBARS value did not differ among group I and III. Our result is in accordance to Jaheed et al. (2020) who found significantly higher values of MDA in albendazole treated group compared to the herbal treated group in Haemonchus infected goats and Dimitrijevic et al. (2012) who reported increased MDA concentration, both in the presence of Strongyle infected sheep and albendazole treatment, when compared to the control group negative for parasites. Locatelli et al. (2004) reported that albendazole provoked an oxidative stress condition, demonstrated through the elevation of TBARS contents suggesting albendazole as a strong ROS and RNS generator. Castro et al., 2016 reported that treatment with albendazole caused oxidative cleavage on calf-thymus DNA, impyling that over-generation of ROS leads to DNA fragmentation.

\section{Total antioxidant capacity}

The TAC assay measures the overall contribution of all the antioxidants present in the sample to its redox balance (Ciuti and Liguri, 2017). The significant depression of TAC levels observed in control group is in agreement with Pivoto et al. (2015) and may be attributed to oxidative stress developed by the helminth parasites. Group II animals treated with AVE showed significantly high value of TAC compared to group I and III. Our result with AVE is supported by the findings of Kaur et al. (2015) who reported excellent antioxidant activities in fractions obtained from Justicia adhathoda using DPPH assay, suggesting AVE as strong and effective scavenger of free radical and hydrogen peroxide radicals. The TAC value of group III, in the present study, did not differ significantly with group I. This result is corroborated by the findings of Locatelli et al. (2004) who reported that animals treated with albendazole seem to be unable to achieve an adequate and persistent antioxidant compensation in relation to ROS and RNS generation and cause deleterious effects on cell homeostasis.

\section{SOD and catalase activities}

Superoxide dismutase and catalase are among the first line defense antioxidants that act to suppress or prevent the formation of free radicals or reactive oxygen species (ROS) in cells. They are fast in neutralizing any molecule with the 
potential of developing into a free radical or any free radical with the ability to induce the production of other radicals (Ighodaro and Akinloye, 2018).

The activities of SOD and catalase were significantly reduced in group I. These results are in accordance with Cinar et al. (2018) who reported decreased SOD and catalase activities in Dicrocoelium and hydatid cyst infected sheep compared to the uninfected control. The decrease in antioxidant enzymes activities, in the present study, proved that the formation of reactive compounds was much higher than the level which could be compensated by the cellular defense system, thus, these compounds may not be converted to less harmful or ineffective metabolites at the sufficient level.

Group II shows significantly increased SOD and catalase activities compared to group I. Our results agree with Adhikary et al. (2016) who found SOD activity restored to normal and increased catalase activity in collagen induced arthritis in mice when given AVE. The result is indicative of ability of AVE to combat oxidative stress following helminth infection. Group III also shows significantly increased SOD and catalase activity on the $5^{\text {th }}$ day and non-significant increase on the $14^{\text {th }}$ day compared to group I. Locatelli et al. (2004) observed that early increase in SOD and catalase activities, in albendazole treated mice, at the beginning of the experiment gradually decreased by the end of the experiment of 10 days compared to the controls. The early increase in SOD activity would render higher hydrogen peroxide production which, in turn is detoxified by high catalase activity at the beginning of the experiment.

\section{Immune status}

The mean \pm SE values of Tlg, IgG and IL-10 of the experimental groups are shown in Table 2. Different helminth parasites generate antibody production through $\mathrm{B}$ cell and $\mathrm{T}$ helper (Th) 2- type responses (Harris and Gause, 2011). B cells are focused on making antibodies, whereas helper $T$ cells are distinguished by the cytokines they secrete.

\section{TIg and IgG}

The values of $\mathrm{Tlg}$ and $\lg \mathrm{G}$ on $5^{\text {th }}$ day were comparable in groups I and III, but significantly lower than the group II. On the $14^{\text {th }}$ day, Tlg and IgG values of the control group were significantly lower than the two treated groups. Our results are in agreement with Bahirathan (1994) who observed that increased level of total $H$. contortus antibodies were accompanied by low faecal egg counts in native and Suffolk ewes. The observation of significantly higher total immunoglobulin concentrations in treated lambs provide evidence that loss of immunoglobulins during blood loss could be the cause for reduced levels of anti-haemonchus antibodies. Our results also find agreement with Sparks et al. (2018) and Aboshady et al. (2020) who reported that increased antiparasite lgG in adults predicts reduced egg counts. The inverse relationship between the levels of IgG and $H$. contortus worm burden was also shown by Silva et al. (2012) after anthelmintic treatment containing albendazole. Vinothapooshan and Sundar (2011) reported that alcoholic extract of $A$. vasica showed increase in neutrophil adhesion and also suppress delayed type of hypersensitivity (DTH) reactions induced by sheep $\mathrm{RBC}$ in mice, thereby, indicating

Table 1: Antioxidant status of sheep treated with AVE and albendazole.

\begin{tabular}{|c|c|c|c|c|c|c|}
\hline & \multicolumn{2}{|c|}{ Group I } & \multicolumn{2}{|c|}{ Group II } & \multicolumn{2}{|c|}{ Group III } \\
\hline & $5^{\text {th }}$ day & $14^{\text {th }}$ day & $5^{\text {th }}$ day & $14^{\text {th }}$ day & $5^{\text {th }}$ day & $14^{\text {th }}$ day \\
\hline TBARS (iM) & $5.43^{a} \pm 0.36$ & $5.03^{d} \pm 0.32$ & $2.64^{b} \pm 0.19$ & $2.74^{\mathrm{e}} \pm 0.12$ & $3.97^{A C} \pm 0.16$ & $5.74^{\mathrm{Bd}} \pm 0.24$ \\
\hline TAC (mM GSH Eq/g Hb) & $0.028^{\mathrm{Aa}} \pm 0.00$ & $0.068^{\mathrm{Bd}} \pm 0.01$ & $0.103^{\mathrm{Ab}} \pm 0.02$ & $0.165^{\mathrm{Be}} \pm 0.01$ & $0.021^{\mathrm{Aa}} \pm 0.00$ & $0.089^{\mathrm{Bd}} \pm 0.01$ \\
\hline $\mathrm{SOD}(\mathrm{U} / \mathrm{g} \mathrm{Hb})$ & $7.10^{\mathrm{a}} \pm 0.61$ & $6.72^{\mathrm{d}} \pm 0.68$ & $14.52^{\mathrm{b}} \pm 0.93$ & $13.77^{\mathrm{e}} \pm 1.15$ & $13.88^{b} \pm 1.49$ & $9.58^{\mathrm{de}} \pm 2.29$ \\
\hline Catalase $(\mathrm{U} / \mathrm{g} \mathrm{Hb})$ & $4.11^{\mathrm{a}} \pm 0.46$ & $5.26^{\mathrm{d}} \pm 0.38$ & $9.07^{b} \pm 0.73$ & $7.47^{e} \pm 0.44$ & $8.01^{b} \pm 0.47$ & $6.06^{\mathrm{d}} \pm 0.33$ \\
\hline
\end{tabular}

Values depict Mean \pm SE.

Means with superscripts abc differ among $5^{\text {th }}$ day values within row $(p<0.05)$.

Means with superscripts def differ among $14^{\text {th }}$ day values within row $(p<0.05)$.

Means with superscripts $A B$ differ among $5^{\text {th }}$ and $14^{\text {th }}$ day values in group within row $(p<0.05)$.

Table 2: Immune status of sheep treated with AVE and albendazole.

\begin{tabular}{lcccccc}
\hline & \multicolumn{2}{c}{ Group I } & \multicolumn{2}{c}{ Group II } & \multicolumn{2}{c}{ Group III } \\
\cline { 2 - 7 } & $5^{\text {th }}$ day & $14^{\text {th }}$ day & $5^{\text {th }}$ day & $14^{\text {th }}$ day & $5^{\text {th }}$ day & $14^{\text {th }}$ day \\
\hline Tlg $(\mathrm{mg} / \mathrm{mL})$ & $4.69^{\mathrm{a}} \pm 0.35$ & $4.10^{\mathrm{d}} \pm 0.18$ & $6.04^{\mathrm{b}} \pm 0.17$ & $5.49^{\mathrm{e}} \pm 0.37$ & $4.45^{\mathrm{Aa}} \pm 0.17$ & $5.92^{\mathrm{Be}} \pm 0.40$ \\
$\lg \mathrm{g}(\mathrm{mg} / \mathrm{mL})$ & $3.98^{\mathrm{a}} \pm 0.21$ & $3.19^{\mathrm{d}} \pm 0.31$ & $5.01^{\mathrm{b}} \pm 0.36$ & $4.65^{\mathrm{e}} \pm 0.51$ & $3.53^{\mathrm{Aa}} \pm 0.31$ & $4.71^{\mathrm{Be} \pm 0.42}$ \\
IL-10 $(\mathrm{ng} / \mathrm{L})$ & $254.33^{\mathrm{a}} \pm 30.79$ & $248.68^{\mathrm{d}} \pm 16.79$ & $287.07^{\mathrm{a}} \pm 11.76$ & $260.42^{\mathrm{d}} \pm 25.93$ & $116.31^{\mathrm{Ab} \pm 6.92}$ & $175.33^{\mathrm{Be} \pm 9.28}$ \\
\hline
\end{tabular}

Values depict Mean \pm SE.

Means with superscripts abc differ among $5^{\text {th }}$ day values within row $(p<0.05)$.

Means with superscripts def differ among $14^{\text {th }}$ day values within row $(p<0.05)$.

Means with superscripts $A B$ differ among $5^{\text {th }}$ and $14^{\text {th }}$ day in group within row $(p<0.05)$. 
the immunostimulatory activity of AVE by potentiating humoral and cellular immunity. Our results with immunoglobulins on administration of AVE corroborates with the above findings.

\section{IL-10}

Group I showed significantly elevated level of IL-10 compared to group III. IL-10, an interleukin produced by Th2 cells has both anti-inflammatory and immunosuppressive properties (de Vries, 1995). Th2-type response has been implicated in helminth parasitic infection (Miller and Horohov, 2006). Schopf et al. (2002) observed that Trichuris muris infected IL-10 deficient mice (transgenic knock-out mice) displayed marked morbidity and mortality. Increase in IL-10 in GI helminth infection gives the animal resistance and protection from developing lethal immunopathology. Other reports such as by Anuradha et al. (2016) also suggests that host response to helminth infection is regulated by cytokine IL-10. In the present study, IL-10 levels of group II did not significantly differ with that of group I, but were found to be numerically higher than the group I. Adhikary et al. (2016) in their study on protective effect of $A$. vasica against auto-immune arthritis in mice using collagen-induced arthritis (CIA) model reported that IL-10 was reduced in CIA mice compared to normal control mice and that treatment with AVE significantly restored IL-10 to normal levels. IL-10, being an anti-inflammatory cytokine, dictates the resolution of inflammation. IL-10 inhibits the production of ROS and RNS by other pro-inflammatory cytokines and therefore, may be important in determining the outcome of immune response. On the other hand, albendazole, in the present study, was found to significantly reduce the IL-10 levels compared to control group. Amoani et al. (2019) reported significant reduction in the IL-10 values following albendazole treatment compared to individuals infected with hookworm or concurrent hookworm and Plasmodium infections. Different cytokine pattern observed in the present experiment for AVE and albendazole treatment was also observed by Bakir et al. (2017) who studied gene expression of IL-10 in albendazole and Myrrh treated mice infected with Trichinella spiralis.

\section{CONCLUSION}

Helminthiasis in sheep cause considerable oxidative stress that was alleviated better by treatment with AVE and good by albendazole. The antioxidant effect of AVE was significantly higher than albendazole treatment.

Immunoglobulins increased on treatment with AVE and albendazole whereas anti-inflammatory and immuno suppressive cytokine IL-10 decreased in albendazole treated animals compared to AVE treated animals.

In conclusion, the anthelmintic activity of Adhatoda vasica surpassed the conventional synthetic drug albendazole in sheep in terms of oxidative and immunological changes in blood.

\section{REFERENCES}

Aboshady, H.M,, Stear, M.J., Johansson, A., Jonal, E. and Bambou, J.C. (2020). Immunoglobulins as biomarkers for gastrointestinal nematodes resistance in small ruminants: A systematic review. Scientific Reports. 10: 7765.

Adhikary, R., Majhi, A., Mahanti, S. and Bishayi, B. (2016). Protective effects of methanolic extract of Adhatoda vasica Nees leaf in collagen induced arthritis by modulation of synovial tolllike receptor-2 expression and release of pro-inflammatory mediators. Journal of Nutrition and Intermediary Metabolism. 3(C). DOI: 10.1016/j.jnim.2015.11.001.

Aebi. H. (1984). Chapter 13. Catalase in vitro. Oxygen Radicals in Biological Systems. 121-126.

Al-Shaibani, I.R.M., Phulan, M.S., Arijo, A. and Qureshi, T. A. (2008). Ovicidal and larvicidal properties of Adhatoda vasica (L.) extracts against gastrointestinal nematodes of sheep in vitro. Pakistan Veterinary Journal. 28(2): 79-83.

Amoani, B., Adu, B., Frempong, M.T., Sarkodie-Addo, T., Nuvor, S.V., Abu, E.K., Harrisson, L.M., Capello, M., Gyan, B. and Wilson, M. D. (2019). Cytokine profiles of Nectar americanus and Plasmodium falciparum co-infected patients in rural Ghana. Cytokine: X, 1(4): https://doi.org/ 10.1016/j.cytox.2019.100014.

Anuradha, R., Munisankar, S., Bhootra., Y., Jagannathan, J., Dolla., C., Kumaran, P., Nutman, T. B. and Babu, S. (2016). IL10 and TGF $\beta$-mediated TH9 responses in a human helminth infection. PLOS Neglected Tropical Diseases. 10(1): 1-13.

Bahirathan, M. (1994). Epidemiology of strongylate nematode and coccidia (Eimeria) infection in sheep with special reference to breed resistance. LSU Historical Dissertations and Thesis. 5849. https://digitalcommons.Isu.edu/gradschool disstheses/5849.

Bakir, H.Y., Ah Attia, R., Mahmoud, A.E. and Ibraheim, Z. (2017). m-RNA gene expression of INF-Y and IL-10 during intestinal phase of Trichinella spiralis after myrrh and albendazole treatment. Iran Journal of Parasitology. 12(2): 188-195.

Castro, L.S.E.P.W., Kviecinski, M.R., Ourique, F., Parisotto, E.B., Grinevicius, V.M.A.S., Correia, J.F.G., Filho, D.W. and Pedrosa, R.C. (2016). Albendazole as a promising molecule for tumour control. Redox Biology. 10: 90-99.

Charlier, J., van der Voort, M., Kenyon, F., Skuce, P. and Vercruysse, J. (2014). Chasing helminths and their economic impact on farmed animals. Trends in Parasitology. 30(7): 361-367.

Cinar, M., Aydenizoz, M., Gokpinar, S. and Camkerten, G. (2018). Evaluation of biochemical parameters and oxidative stress in sheep naturally infected with Dicrocoelium dendriticum and hydatid cysts. Turkish Journal of Veterinary and Animal Sciences. 42: 423-428.

Ciuti, R. and Liguri, G. (2017). A novel assay for measuring total antioxidant capacity in whole blood and other biological samples. Journal of Biomedical Science and Engineering. 10: $60-76$.

de Vries, J.E. (1995). Immunosuppressive and anti-inflammatory properties of interleukin 10. Annals of Medicine. 27(5): 537-541. 
Dimitrijevic, B., Borozan, S., Katic-Radivojevic, S. and Stojanovic, S. (2012). Effects of infection intensity with Strongyloides papillosus and albendazole treatment on development of oxidative/nitrosative stress in sheep. Veterinary Parasitology. 186: 364-375.

Harris, N. and Gause, W.C. (2011). B cell function in the immune response to helminthes. Trends in Immunology. 32(2): 80-88.

Ighodaro, O.M. and Akinloye, O.A. (2018). First line defence antioxidants-superoxide dismutase, catalase and glutathione peroxidase: Their fundamental role in the entire antioxidant defence grid. Alexandria Journal of Medicine. 54(4): 287-293.

Jaheed, E., Mohamed, A.H., Nasr, S.M., Mahran, K.M.A., Mohammed, F.F., Sedky, D. and Abou-Zeina, H.A.A. (2020). Therapeutic effect of Balanites aegyptica fruit's ethanol extract in Egyptian Baladi goats experimentally infected with Haemonchus contortus: Blood serum biochemical, oxidative stress markers and pathological studies. Egyptian Journal of Veterinary Sciences. 51(1): 119-136.

Kaur, A., Kaur, D. and Arora, S. (2015). Evaluation of antioxidant and mutagenic potential of Justicia adhatoda leaves extract. African Journal of Biotechnology. 14(21): 18071819.

Lateef, M., Iqbal, Z., Khan, M.N., Akthar, M.S. and Jabbar, A. (2003). Anthelmintic activity of Adhatoda vesica roots. International Journal of Agriculture and Biology. 5(1): 86-90.

Locatelli, C., Pedrosa, R.C., De Bem, A.F., Pasa, T.B.C., Cordova, A.A.S., Wilhem-Filho, D. (2004). A comparative study of albendazole and mebendazole-induced, time-dependent oxidative stress. Redox Report. 9(2): 89-95

Miller, J.E. and Horohov, D.W. (2006). Immunological aspects of nematode parasite control in sheep. Journal of Animal Science. 84(13): E124-E132.
Misra, H.P. and Fridovich, I. (1972). The role of superoxide anion in the autooxidation of epinephrine and a simple assay for SOD. Journal of Biological Chemistry. 247: 3170-3175.

Ohkawa, H., Ohishi, N. and Yagi, K. (1979). Assay for lipid peroxides in animal tissues by thiobarbituric acid reaction. Analytical Biochemistry. 95: 351-358.

Pivoto, F.L., Torbitz, V.D., Aires, A.R., da Rocha, J.F.X., Severo, M.M., Grando, T.H., Pieter, M., Moresco, R.N., da Rocha, J.B.T. and Leal, M. L.R. (2015). Oxidative stress by Haemonchus contortus: Influence of treatment with zinc edetate. Research in Veterinary Science. 102: 22-24.

Rashid, S. and Irshadullah, M. (2019). Evaluation of antioxidant and oxidant status of goats (Capra aegagrus hircus) naturally infected with Haemonchus contortus. Journal of Helminthology. 94: E6. DOI: 10.1017/S0022149X19000117.

Schopf, L.R., Hoffmann, K.F., Cheever, A.W., Urban, Jr. J.F. and Wynn, T.A. (2002). IL-10 is critical for host resistance and survival during gastrointestinal helminth infection. The Journal of Immunology. 168: 2383-2392.

Silva, B.F., Bassetto, C.C. and Amarante, A.F.T. (2012). Immune response in sheep naturally infected with Oestrus ovis (Diptera: Oestridae) and gastrointestinal nematodes. Veterinary Parasitology. 190: 120-126.

Soni, S., Anandjiwala, S., Patel, G. and Rajani, M. (2008). Validation of different methods of preparation of Adhatoda vasica leaf juice by quantification of total alkaloids and vasicine. Indian Journal of Pharmaceutical Sciences. 70(1): 36-42.

Sparks, A.M., Watt, K., Sinclair, R., Pilkington, J.G., Pemberton, J.M., Johnston, S.E., McNielly, T.N. and Nussey, D.H. (2018). Natural selection on antihelminth antibodies in a wild mammal population. The American Naturalist. 192(6): 745-760.

Vinothapooshan, G. and Sundar, K. (2011). Immunomodulatory activity of various extracts of Adhatoda vasica Linn. in experimental rats. African Journal of Pharmacy and Pharmacology. 5(3): 306-310. 